\title{
Radiofrequency fistulotomy: a better alternative for treating low anal fistula
}

\author{
Fine Morning Hospital and Research Center, Nagpur, India
}

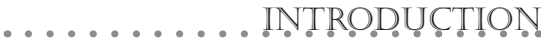

The classic lay-open technique is still the most favored procedure for anal fistula. Slitting the complete tract, starting from the external opening and proceeding to the internal opening, is the basis for traditional fistulotomy. ${ }^{1}$

However, this conventional procedure at times encounters brisk bleeding from the cut surfaces. The dissection causes unpredictable tissue trauma, thereby aggravating the postoperative pain and edema, delaying the return to work and necessitating intake of stronger doses of analgesics for longer periods. The risk of wound complications like infection, delayed wound healing and recurrence are but a few of the other areas of concern accompanying the traditional method.

Instead of using the scalpel, we have employed radiofrequency waves to perform the same lay-open procedure for treatment of low anal fistula (low trans-sphincteric and intersphincteric fistula). The surgical principle in radiofrequency surgery is that the offending tissue obstructing the path of the high-powered radio waves is destroyed. The intracellular tissue water that provides the resistance in the process is instantly vaporized without causing heat and damage, unlike what takes place in electrosurgery. This tissue vaporization also results in significant hemostasis without actually burning the tissue. ${ }^{2}$ In addition, there is no danger of the patient suffering any shock or burn in the process. The radiofrequencygenerating unit is provided with a terminal to which different electrodes can be attached to suit the exact requirement of the procedure. We have used a ball electrode for coagulation, a needle electrode to incise the fistula tract and a round loop electrode to shave the tract tissue in our procedures. The surgical radiofrequency generator that we have been using is the dual frequency $4 \mathrm{MHz}$ unit from Ellman International (Hewlett, New York).

. METHODS

The study included 232 consecutive patients with low anal fistula. A low anal fistula was taken to be one with a tract that does not extend above the level of the anal crypts and usually opens at this level into the anal canal. All of these patients were followed over a period averaging 15 months (range: 14-18 months). The following types of fistula were excluded from the study: high transsphincteric fistulas with or without high blind tract, supra-sphincteric, extra-sphincteric and horseshoe fistulas, as well as fistulas associated with inflammatory bowel disease.

\section{Radiofrequency fistulotomy procedure}

All the patients were operated on under short-duration general anesthesia. The step-bystep approach to our procedure was as follows:

1. Injection of methylene blue dye with hydrogen peroxide ${ }^{3}$ into the external opening of the fistula. This helped in obtaining a clear display of the main fistula tract. It also opened up the secondary or side tracts if present.

2. While viewing through the anoscope, a directional probe was gently passed through the external opening until it came out from the internal opening, which was demarcated by the blue indentation of the dye.

3. The skin overlying the probe in the fistula tract was coagulated by moving the ball electrode over its complete length. This was 
found to reduce the amount of bleeding when the tract was slit opened thereafter.

4. The tract was cut opened along the line of the probe with the help of the needle electrode, switched to the 'cut and coagulation' mode. This reduced the bleeding while cutting and made the dissection smooth enough to avoid any drag on the tissues.

5. The wound edges were coagulated with the ball electrode kept in the 'coagulation' mode. This obviated the possibility of any ooze from the wound surface.

6 . The tract, along with the surrounding infected fibrotic tissue was curetted with the loop electrode in the 'cut and coagulation' mode. As cutting and coagulation were achieved simultaneously, the brisk bleeding often encountered in the conventional knife and scissors dissection was avoided.

7. Finally, the edges of the wound were shaved, using the loop electrode to create a pearshaped wound tapering towards the anus.

The patients were discharged on the evening of the procedure. They were asked to take a tablet containing $50 \mathrm{mg}$ of diclofenac sodium and $10 \mathrm{mg}$ of serratiopeptidase twice a day for seven days and, thereafter, as and when they felt pain. The postoperative care consisted of the application of antiseptic cream over the wound twice a day after a warm sitz bath.

............. RESUITS

The mean procedure time was $13 \mathrm{~min}$ utes. This was recorded by an independent observer, and was calculated as the total time required from inserting the probe in the fistula tract to the application of dressing over the wound.

The patients were discharged as soon as they became fully mobilized without the need for assistance from a nurse for personal hygiene and dressing. As the procedure was carried out under short-duration general anesthesia, most of the patients were able to go home within eight hours of the procedure.

The period off work is defined as the total time taken to return to the usual activity of domestic and social life at the patient's discretion. Patients operated on via radiofrequency fistulotomy procedures were able to resume their routine within a week of the procedure (a mean of 4 days).

A mean of 18 doses of analgesic were required, where one dose equaled one tablet of the combination of diclofenac sodium 50 $\mathrm{mg}$ and serratiopeptidase $10 \mathrm{mg}$.

The wound healing time was taken as the period needed for complete epithelization of the fistulotomy wound. The average time taken for wounds to heal was 67 days, ranging from 42 to 75 days.

Four patients from our study were found to have premature closure of the proximal wound while the distal end remained unhealed. The healed edges of the proximal part of the wound were slit opened under local anesthesia. Following this, the wounds healed in two of these patients. However, in the remaining two, they failed to heal. These two cases were termed 'failure of wound healing' rather than recurrence $(0.8 \%)$.

None of the patients had any interference with continence. With a follow-up of at least 15 months, the recurrence rate was as low as $1.7 \%$ ( 4 out of 232 patients).

\section{Complications}

No major complications were encountered with the radiofrequency device. However, failure to monitor the exact power requirement from the unit, in a few of the initial cases, resulted in the use of higher power rates than necessary, thereby causing smoke and charring. This was rectified in the subsequent procedures.

. . . . . . . . . DISGCQUSSIION

Radiofrequency surgery uses a very high frequency radio wave. ${ }^{4}$ The tissue damage caused by radiofrequency is superficial and is comparable with the results from the harmonic scalpel and laser.

Radiofrequency surgery creates minimal collateral heat damage in the tissue, thus resulting in rapid healing and leaving no ugly scar. ${ }^{5}$ The unit does not require any recurring maintenance except for the normal care during its handling and use.

In comparison with other treatment techniques for anal fistula, our study produced results that were equal to or even better than obtained using these others, such as marsupialization, ${ }^{6,7}$ sphincter preserving procedures, ${ }^{8}$ coring-out technique, ${ }^{9}$ instillation of fibrin glue, ${ }^{10-12}$ flap procedures, ${ }^{13,14}$ excision of fistula and closure of internal opening, ${ }^{15}$ incision, and lay-open ${ }^{16}$ using rubber seton ${ }^{17}$ or medicated seton. ${ }^{18}$ The improvement came in terms of wound healing, wound complications, interference with continence and recurrence (Table 1).

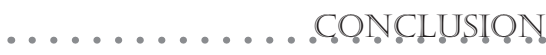

The fistulotomy procedure using a radiofrequency technique has distinct advantages like a short operation time, minimal blood loss, early return to normal activity and a low recurrence rate. We found from our study that this method can serve as a useful addition for improving on the results from the conventional procedure for treating low anal fistula.

\begin{tabular}{|c|c|c|}
\hline Observations & Our series & Other series \\
\hline Time for wound healing & 67 days & $\begin{array}{l}\text { Marsupialization: } 42 \text { days }^{6} \\
\text { Lay-open: } 70 \text { days }^{6}\end{array}$ \\
\hline Failure of wound healing & $0.8 \%$ & $\begin{array}{l}\text { Fibrin glue: } 29 \%^{7}-100 \%^{8} \\
\text { Flap: } 36 \%^{9}\end{array}$ \\
\hline Recurrence & $1.7 \%$ & $\begin{array}{l}\text { Sphincter preserving procedure: } 5 \%^{10} \\
\text { Marsupialization: } 10 \%^{11} \\
\text { Seton: } 22 \%^{12} \\
\text { Flap: } 33 \%^{13} \\
\text { Fibrin glue: } 40 \%^{14}\end{array}$ \\
\hline Incontinence for flatus & None & $\begin{array}{l}\text { Lay-open: } 10 \%{ }^{16} \\
\text { Marsupialization: } 20 \%{ }^{6}\end{array}$ \\
\hline Incontinence for liquids & None & Excision of fistula with closure of internal opening: $11 \% 15$ \\
\hline Delayed healing & None & Open coring-out (function-preserving) technique: $15 \% 17$ \\
\hline Abscess formation & None & Medicated seton: $3-5 \%^{18}$ \\
\hline
\end{tabular}


1. García-Aguilar J, Davey CS, Le CT, Lowry AC, Rothenberger DA. Patient satisfaction after surgical treatment for fistula-inano. Dis Colon Rectum. 2000;43(9):1206-12.

2. Pfenninger JL, Zainea, GG. Common anorectal conditions: Part II. Lesions. Am Fam Physician. 2001;64(1):77-88

3. Gunawardhana PA, Deen KI. Comparison of hydrogen peroxide instillation with Goodsall's rule for fistula-in-ano. ANZ J Surg. 2001;71(8):472-4.

4. Plant RL. Radiofrequency treatment of tonsillar hypertrophy. Laryngoscope. 2002;112(8 Pt 2):20-2.

5. Rex J, Ribera M, Bielsa I, Paradelo C, Ferrándiz C. Surgical management of rhinophyma: report of eight patients treated with electrosection. Dermatol Surg. 2002;28(4):347-9.

6. Ho YH, Tan M, Leong AF, Seow-Choen F. Marsupialization of fistulotomy wounds improves healing: a randomized controlled trial. Br J Surg. 1998;85(1):105-7.

7. Ereifej S, Lestár B, Hornok L, Ritter L, Kiss J. Az analis fistula kezelése. [Treatment of anal fistulas]. Magy Seb. 2000;53(6):263-6.

8. Iwadare J. Sphincter-preserving techniques for anal fistulas in Japan. Dis Colon Rectum. 2000;43(10 Suppl):S69-77.

9. Hongo Y, Kurokawa A, Nishi Y. Open coring-out (functionpreserving) technique for low fistulas. Dis Colon Rectum. 1997;40(10 Suppl):S104-6.

10. Sentovich SM. Fibrin glue for anal fistulas: long-term results. Dis Colon Rectum. 2003;46(4):498-502.

11. Aitola P, Hiltunen KM, Matikainen M. Fibrin glue in perianal fistulas - a pilot study. Ann Chir Gynaecol. 1999;88(2):136-8.

12. Chan KM, Lau CW, Lai KK, et al. Preliminary results of using a commercial fibrin sealant in the treatment of fistula-in-ano. J R Coll Surg Edinb. 2002;47(1):407-10.

13. Sonoda T, Hull T, Piedmonte MR, Fazio VW. Outcomes of primary repair of anorectal and rectovaginal fistulas using the endorectal advancement flap. Dis Colon Rectum.
2002:45(12):1622-8

14. Mizrahi N, Wexner SD, Zmora et al. Endorectal advancement flap: are there predictors of failure? Dis Colon Rectum. 2002;45(12):1616-21.

15. Gustafsson UM, Graf W. Excision of anal fistula with closure of the internal opening: functional and manometric results. Dis Colon Rectum. 2002;45(12):1672-8.

16. Malouf AJ, Buchanan GN, Carapeti EA, et al. A prospective audit of fistula-in-ano at St. Mark's hospital. Colorectal Dis. 2002;4(1):13-9.

17. Theerapol A, So BY, Ngoi SS. Routine use of setons for the treat ment of anal fistulae. Singapore Med J. 2002;43(6):305-7.

18. Mohite JD, Gawai RS, Rohondia OS, Bapat RD. Ksharsootr (medicated seton) treatment for fistula-in-ano. Indian J Gastroenterol. 1997;16(3):96-7.

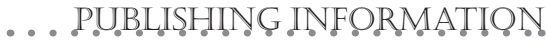

Pravin Jaiprakash Gupta, MS (General Surgery). Fine Morning Hospital and Research Center, Nagpur, India.

Sources of funding: None

Conflict of interest: None

Date of first submission: June 11, 2003

Last received: October 23, 2003

Accepted: December 22, 2003

\section{Address for correspondence:}

Dr. Pravin J. Gupta

Gupta Nursing Home,

D/9, Laxminagar,

Nagpur - 440022

India.

Tel. (+91) 7122231047

Fax. $(+91) 7122547837$

E-mail:drpig@nagpur.dot.net.in

$\ldots \ldots \ldots \ldots \ldots \ldots \ldots \ldots \ldots$ R $_{0} \mathrm{U}_{0} \mathrm{MO}_{0}$

Fistulotomia por radiofreqüência: uma alternativa melhor para o tratamento da fístula anal baixa.

CONTEXTO: Uma grande variedade de métodos pode ser utilizada no manejo da fístula anal baixa. No entanto, o simples método de abertura e exposição da fístula (fistulotomia) é ainda considerado o melhor deles.

MATERIAIS E MÉTODOS: Um método modificado para a abordagem de fistulotomia é discutido. Este estudo descreve o procedimento, em que foi usada uma técnica de cirurgia por radiofrequência, e o seu resultado em 232 pacientes com fístula anal baixa. Os pacientes foram acompanhados por um período de 15 meses.

RESULTADOS: Os pacientes tiveram alta no mes- mo dia do procedimento. A média de tempo sem trabalhar foi de quatro dias. A média de tempo para cicatrização foi de 67 dias. Quatro complicaçōes da ferida, caracterizadas por fechamento prematuro da área externa da ferida, foram observadas, exigindo incisōes da região da periferia. Duas destas feridas permaneceram abertas. $\mathrm{O}$ índice de recorrência foi de 1,7\%.

CONCLUSÃO: Nesta época em que a ênfase é dada a critérios como mínima permanência no hospital, redução da dor pós-operatória, retorno precoce ao trabalho e índices de recorrência baixos e comparáveis, existe um futuro para o procedimento de fistulotomia por radiofreqüência.

PALAVRAS-CHAVE: Fístula retal. Recidiva. Cirurgia retal. Ânus. Ondas de rádio. 